\title{
PENDEKATAN BELAJAR MELALUI KARYA POSTER DALAM MENGENALKAN MATERI GLOBALISASI PADA MATA PELAJARAN PKN UNTUK SISWA KELAS IV SD 1 NGEMBALREJO KABUPATEN KUDUS
}

\author{
Deka Setiawan \\ PGSD FKIP Universitas Muria Kudus \\ deka_setiawan@umk.ac.id
}

\begin{abstract}
Research Approach Learning Through Work Poster In Introduce Content Globalization On Civics Lesson For Students Grade IV SD 1 Ngembalrejo Interest problem in this research there are three that are the focus does skills of teachers in managing learning civics with poster work approach in the introduction of globalization for students SD 1 Ngembalrejo Kudus, Knowing students' activity in learning civics with the approach of the work of the posters in the introduction of globalization for elementary students SD 1 Ngembalrejo Kudus, Exposing the learning outcomes of students in learning civics approach works poster in the introduction of globalization for elementary students 1 Ngembalrejo.

Results of action research showed an increase learning outcomes Civics approaches to learning through the work of the poster to introduce the material globalization. Improved learning outcomes is proved by research data cycle I and cycle II. This is evidenced by the increase in the average value of pre cycle class until the second cycle. The value in the pre-cycle evaluation results using data from test scores were pure. Based on these data, the known value of the average student with classical completeness $60.4540 .91 \%$, there were 13 students who have not completed and 9 students who pass. Teachers' teaching skills in managing the class on civics learning approaches to learning through the work of the poster to introduce the material in the first cycle of globalization gained $80.17 \%$ in the percentage of both criteria, on the second cycle increased to $84.91 \%$ with good criterion. Activities of students in participating Civics Education materials globalization approaches to learning through the work of the poster to introduce the material in the first cycle of globalization gained $75.28 \%$ at both criteria, increased in the second cycle into $84.66 \%$ are in the very good Civics criteria approach learning through the work of the poster to introduce the material globalization can improve learning outcomes in the cognitive, affective and psychomotor. The increase in the cognitive aspects seen in the first cycle to the second cycle is the average value of 69.55 rose to 77.05, the aspect of affective seen from the first cycle to the second cycle of $62.5 \%$ ie sufficient criteria rose to $84.43 \%$, with good criterion, while the aspect of psychomotor seen the first cycle to the second cycle of $56.02 \%$ is sufficient criteria increased to $84.21 \%$ at both criteria.
\end{abstract}

Keywords : Learning Approach,Poster, Civic Education

\begin{abstract}
ABSTRAK
Penelitian Pendekatan Belajar Melalui Karya Poster Dalam Mengenalkan Materi Globalisasi Pada Mata Pelajaran PKn Untuk Siswa Kelas IV SD 1 Ngembalrejo Kabupaten Kudus Tujuan masalah dalam penelitian ini ada tiga yang menjadi fokus dilakukannya
\end{abstract}

\section{Jurnal Refleksi Edukatika}

Vol. 6 No. 2 Juni 2016 
penelitian.Mengetahui keterampilan guru dalam mengelola pembelajaran PKn dengan pendekatan karya poster dalam pengenalan globalisasi untuk siswa SD 1 Ngembalrejo Kabupaten Kudus,Mengetahui aktivitas siswa dalam pembelajaran PKn dengan pendekatan karya poster dalam pengenalan globalisasi untuk siswa SD 1 Ngembalrejo Kabupaten Kudus,Memaparkan hasil belajar siswa dalam pembelajaran PKn PKn dengan pendekatan karya poster dalam pengenalan globalisasi untuk siswa SD 1 Ngembalrejo Kabupaten Kudus.

Hasil penelitian tindakan kelas menunjukkan adanya peningkatan hasil belajar PKn menggunakan pendekatan belajar melalui karya poster untuk mengenalkan materi globalisasi. Peningkatan hasil belajar tersebut terbukti dengan data hasil penelitian siklus I dan siklus II. Hal ini dibuktikan dengan adanya peningkatan nilai rata-rata kelas dari prasiklus hingga siklus II. Nilai pada hasil evaluasi pra siklus menggunakan data dari nilai ulangan murni. Berdasarkan data tersebut, diketahui nilai rata-rata siswa 60,45 dengan ketuntasan klasikal 40,91\% terdapat 13 siswa yang belum tuntas dan 9 siswa yang tuntas. Keterampilan mengajar guru dalam mengelola kelas pada pembelajaran PKn menggunakan pendekatan belajar melalui karya poster untuk mengenalkan materi globalisasi pada siklus I memperoleh persentase $80,17 \%$ berada pada kriteria baik, pada siklus II meningkat menjadi 84,91\% dengan kriteria baik. Aktivitas siswa dalam mengikuti Pembelajaran PKn materi globalisasi menggunakan pendekatan belajar melalui karya poster untuk mengenalkan materi globalisasi pada siklus I memperoleh $75,28 \%$ berada pada kriteria baik,meningkat pada sikus II menjadi 84,66\% berada pada kriteria sangat baik.Pembelajaran PKn menggunakan pendekatan belajar melalui karya poster untuk mengenalkan materi globalisasi dapat meningkatkan hasil belajar pada aspek kognitif, afektif dan psikomotorik. Peningkatan pada aspek kognitif dilihat pada siklus I ke siklus II yaitu nilai rata-rata 69,55 naik menjadi 77,05, Pada aspek afektif dilihat dari siklus I ke siklus II yaitu dari $62,5 \%$ kriteria cukup naik menjadi 84,43\%, dengan kriteria baik, Sedangkan Pada aspek psikomotorik dilihat siklus I ke siklus II yaitu dari 56,02\% kriteria cukup naik menjadi $84,21 \%$ berada pada kriteria baik.

Kata Kunci : Pendekatan Belajar,Poster,Pendidikan Kewarganegaraan

\section{PENDAHULUAN}

Dampak negatif dari keterkaitan globalisasi dalam ilmu pengetahuan dan teknologi untuk anak-anak usia sekolah antara lain kekerasan dengan rekannya sendiri, pelecehan seksual, kecanduan obat-obat terlarang, minum-minuman keras, bunuh diri dan lain sebagainya. Hal ini menggambarkan bahwa pendidikan moral yang dilakukan selama ini belum menyentuh ranah kesadaran siswa. Menurut Mastur (2007: 1-2) bahwa mata pelajaran Pendidikan Kewarganegaraan $(\mathrm{PKn})$ merupakan mata pelajaran yang membahas pada pembentukan warga negara yang memahami dan mampu melaksanakan hak-hak dan kewajibannya untuk menjadi warga Negara Indonesia yang cerdas, terampil, dan berkarakter yang di-amanatkan oleh Pancasila dan UUD 1945. Peran mata pelajaran PKn diharapkan memiliki pesanpesan moral yang disampaikan oleh guru di depan kelas, tidak mampu menjiwai setiap gerak langkah siswa dalam kehidupan masyarakatnya. Hal ini tentunya, disebabkan oleh keringnya pembelajaran yang dirasakan siswa, materi moral dianggap sebagai bahan kajian teoritis semata..Guru hendaknya mampu berperan sebagai pembimbing untuk menuntun siswa memulai proses belajar, 
memimpin siswa agar hasil proses belajar sesuai dengan tujuan pendidikan, serta sebagai fasilitator dalam mempersiapkan kondisi yang memungkinkan siswa untuk melakukan kegiatan belajar.

Proses pembelajaran PKn yang dirancang oleh guru ternyata belum mampu memiliki asas kebermanfaatan untuk siswa dikalangan Sekolah Dasar. Salah satu penerapan pembelajaran di kelas sekolah Dasar melalui penggunaan media pembelajaran yang sesuai dengan karakteristik materi pembelajaran PKn. Media pembelajaran merupakan salah satu komponen pembelajaran yang mempunyai peranan penting dalam proses pembelajaran. Bovee (dalam Sanaky, 2009: 3) memaknai, media sebagai sebuah alat yang mempunyai fungsi menyampaikan pesan. Pemanfaatan media seharusnya merupakan bagian yang harus mendapat perhatian guru sebagai fasilitator dalam setiap kegiatan pembelajaran. Oleh karena itu tiap-tiap guru perlu mempelajari bagaimana menetapkan media pembelajaran agar dapat mengefektifkan pencapaian tujuan pembelajaran dalam proses belajar mengajar.

Media pembelajaran berfungsi sebagai akomodasi siswa Sekolah Dasar yang lemah dan lambat dalam menerima serta memahami isi pelajaran yang disajikan melalui bentuk teks (disampaikan secara verbal). Pembelajaran menggunakan media berupa pengalaman secara kongkret melalui proses pengamatan dan pendengaran membuat siswa Sekolah Dasar memahami materi yang akan diajarkan.

Keterlibatan siswa Sekolah Dasar melalui media visual dapat mengajak peserta didik berpikir dan menghayati pesan yang disampaikan. Prinsip utama pemilihan media pembelajaran harus didasarkan pada tujuan belajar yang ditentukan dengan mengingat karakteristik khusus yang ada pada kelompok belajar. Pengenalan materi globalisasi dalam mata pelajaran PKn untuk siswa Sekolah
Dasar diterapkan media pembelajaran yang dapat memberikan pesan secara nyata dengan harapan peserta didik mampu mengidentifikasi berdasarkan permasalahan di lingkungan melalui karya seni yang memiliki nilai keindahan dengan moralitas (etika) bangsa Indonesia.Stimulasi kepekaan estetik dilakukan oleh guru Sekolah Dasar dengan media pembelajaran berupa karya seni secara visual seperti pembuatan poster globalisasi menjadikan kepekaan siswa untuk menggugah dan membangunkan kreativitas yang dapat meningkatkan pembelajaran mata pelajaran PKn.

Berdasarkan uraian latar belakang mengenai permasalahan dalam pembelajaran PKn mengenai materi globalisasi yang terdapat di kelas IV semester 2, maka peneliti mengambil judul "Pendekatan Belajar Melalui Karya Poster Dalam Mengenalkan Materi Globalisasi Pada Mata Pelajaran PKn Untuk Siswa Kelas IV SD 1 Ngembalrejo Kabupaten Kudus". Objek penelitian mengambil tempat di SD 1 Ngembalrejo Kabupaten Kudus dengan alasan bahwa lembaga pendidikan tersebut sesuai dengan karakteristik peserta didik yang memiliki lingkungan industri yang disesuaikan materi globalisasi.

Tujuan masalah dalam penelitian ini ada tiga yang menjadi fokus dilakukannya penelitian.

a) Mengetahui keterampilan guru dalam mengelola pembelajaran PKn dengan pendekatan karya poster dalam pengenalan globalisasi untuk siswa SD 1 Ngembalrejo Kabupaten Kudus.

b) Mengetahui aktivitas siswa dalam pembelajaran PKn dengan pendekatan karya poster dalam pengenalan globalisasi untuk siswa SD 1 Ngembalrejo Kabupaten Kudus.

c) Memaparkan hasil belajar siswa dalam pembelajaran PKn PKn dengan pendekatan karya poster dalam pengenalan globalisasi untuk siswa SD 1 Ngembalrejo Kabupaten Kudus.

\section{Jurnal Refleksi Edukatika}




\section{METODE PENELITIAN}

Sesuai dengan objek kajian dalam penelitian ini berupa kegiatan pembelajaran PKn yang berkaitan dengan media karya poster dan aktivitas siswa kelas IV SD 1 Ngembalrejo Kabupaten Kudus serta tidak lepas dari pengaruh faktor-faktor dalam pelaksanaan pembelajaran untuk mengenalkan globalisasi kepada siswa.Untuk memperoleh simpulan yang komprehensif pada penelitian ini digunakan Penelitian Tindakan Kelas. Menurut Suwandi (2011:12) penelitian tindakan kelas didefinisikan sebagai suatu pencermatan terhadap kegiatan belajar berupa sebuah tindakan yang sengaja dimunculkan dan terjadi dalam sebuah kelas secara bersamaan, tindakan tersebut diberikan oleh guru atau dengan arahan guru yang dilakukan oleh siswa. Menurut Arikunto (2010: 3) penelitian tindakan kelas adalah suatu pencermatan terhadap kegiatan belajar berupa sebuah tindakan yang sengaja dimunculkan dan terjadi dalam sebuah kelas secara bersama.

Data kualitatif dalam penelitian ini diperoleh dari elemen-elemen yang terkait dalam fokus penelitian. Langkah-langkah yang akan dilakukan berupa observasi, wawancara, dokumentasi. Analisis data menggunakan analisis kualitatif dan kuantitatif. Muslich (2012: 91) menyatakan bahwa analisis data adalah upaya memilih, memilah, membuang dan menggolongkan data untuk menjawab dua hal pokok yaitu tema apa yang ditemukan dan seberapa jauh data dapat mendukung tema penelitian.

\section{PEMBAHASAN}

Penelitian ini ini dibuat setelah peneliti melakukan observasi lapangan untuk memperoleh permasalah pembelajaran yang ada di SD 1 Ngembalrejo Kudus, khususnya kelas IV dalam pembelajaran PKn. Penelitian ini dilaksanakan pada bulan November sampai Juli dan dilakukan dalam dua siklus. Siklus pertama dua pertemuan dan siklus kedua dua pertemuan. Setiap pertemuan, peneliti dibantu oleh teman sejawat untuk mengobservasi dan mendokumentasikan pelaksanaan pembelajaran.

Kondisi awal hasil wawancara pada tanggal 15 September 2015 dengan ibu Trisunarsih (sebagai guru kelas) diketahui bahwa hasil belajar PKn kelas IV SDN 1 Ngembalrejo Kudus semester 1 tahun pelajaran 2015/2016 masih rendah. Hal ini terbukti dari nilai ulangan yang diperoleh siswa dan diambil peneliti sebagai nilai pra siklus masih terdapat siswa yang memperoleh nilai di bawah KKM. Dari keseluruhan siswa yang berjumlah 22 siswa, masih terdapat siswa yang mendapat nilai di bawah KKM PKn yaitu 65 . Terdapat 9 siswa yang sudah mencapai KKM (41\%) dan 13 orangsiswa yang belum mencapai KKM (59\%). Hal inidikarenakan guru masih menggunakan model pembelajaran langsung. Guru memberikan penjelasan kepada siswa tanpa melibatkan keaktifan siswa, sehingga membuat siswa merasa jenuh dan bosan. Akibatnya pada saat pembelajaran berlangsung hanya guru saja yang aktif dan siswa hanya pasif mendengarkan penjelasan dari guru.

Selain itu guru juga belum pernah mengajak siswa untuk belajar dengan media pembelajaran melalui poster yang dapat mengaktifkan siswa dalam pembelajaran. Ini menyebabkan siswa tidak mampu berpikir secara konkret untuk menggali pengetahuan yang dimilikinya. Kondisi seperti itu sangat berdampak pada peningkatan hasil belajar siswa yang nantinya akan menjadi kurang baik atau kurang maksimal.

Berdasarkan hasil wawancara struktur dengan ibu Trisunarsih (sebagai guru kelas), maka peneliti menerapkan pendekatan belajar melalui karya poster untuk mengenalkan materi globalisasi. Perolehan nilai rata-rata 
hasil belajar PKn kelas IV SD 1 Ngembalrejo Kudus sebesar 60,45 dengan rincian nilai tertinggi 85 dan nilai terendah 40. Dengan acuan $\mathrm{KKM} \geq 65$. Dari 22 siswa, yang dinyatakan tuntas ada 9 siswa $(40,91 \%)$ dan yang tidak tuntas ada 13 siswa $(59,09 \%)$. Hal ini menunjukkan bahwa di dalam pembelajaran masih banyak berpusat pada guru dan berkesan monoton. Kegiatan pembelajaran yang dilakukan menjadi kurang bermakna bagi siswa sehingga hasil belajar menjadi rendah. Berdasrkan hasil belajar yang rendah dari siswa kelas IV SDN 1 Ngembalrejo Kudus, maka untuk itu perlu diadakan tindakan untuk meningkatkan hasil belajar siswa tersebut.

Hasil penelitian keterampilan guru menggunakan pendekatan belajar melalui karya poster untuk mengenalkan materi globalisasi menunjukkan pada siklus I pertemuan 1 mendapat skor 92 dengan persentase $79,31 \%$ kriteria baik. Pada pertemuan 2 terjadi peningkatan skor menjadi 94 dengan persentase $81,03 \%$ kriteria baik. Keterampilan mengajar guru pada siklus I menunjukkan masih ada kekurangan dalam proses pembelajaran, yaitu mengkondisikan kelas kurang dan mengaitkan pembelajaran dengan pengetahuan lain. Kekurangan tersebut perlu dilakukan perbaikan di siklus 2 dengan cara meningkatkan minat belajar siswa, mengasosiasi pembelajaran dengan mengaitkan pengetahuan lain serta perlu memaksimalkan penerapan pendekatan belajar yang dilakukan guru. Seperti yang diungkapkan Djamarah (2011: 169), guru harus selalu memberikan kepada siswa cukup banyak hal yang perlu dipikirkan dan dilakukan. Guru harus memelihara minat siswa dalam belajar, yaitu dengan memberikan kebebasan tertentu untuk berpindah dari 1 aspek ke aspek lain aspek pelajaran dengan situasi belajar. Selain itu Djamarah (2011: 172) menyebutkan guru juga harus mampu mengasosiasikan pembelajaran dengan pengetahuan lain. Pengalaman siswa baik yang didapat dilingkungan sekolahmaupun diluar sekolah dapat dimanfaatkan ketika guru sedang ,mengajarkan materi pembelajaran. Kondisi yang terjadi setelah dilakukan perbaikan yaitu terjadi peningkatan keterampilan mengajar guru serta pembelajaran dikelas semakain kondusif karena minat belajar siswa lebih meningkat dari sebelumnya. Pada siklus II pertemuan 1 keterampilan mengajar guru mendapat skor 95 dengan persentase $81,89 \%$ dengan sangat baik. Sedangkan pada siklus II pertemuan 2 mengalami peningkatan dibanding pertemuan sebelumnya dan siklus sebelumnya. Pada pertemuan 2 mendapat skor 102 dengan persentase $87,93 \%$ dengan kriteria sangat baik.

Tindakan siklus II guru memberikan teguran secara halus dan menfokouskan perhatian siswa dengan mengkondisikan kelas. Hal ini dilakukan supaya siswa tidak ramai sendiri selama proses pembelajaran. Guru memberikan pengarahan dengan jelas ketika terdapat siswa yang belum paham, selain itu guru juga menerapkan keterampilan dalam membimbing seluruh siswa dilakukan lebih mendalam supaya tidak mengalami kebingungan. Guru menanggapi dengan baik terhadap penyampaian hasil diskusi yang disampaikan oleh siswa dan mengarahkan siswa untuk bertanya lebih banyak. Siklus II menunjukkan adanya peningkatan, meliputi guru mampu mengolah kelas sehingga pembelajaran dapat berjalan lebih efektif dan mengolah kegiatan diskusi dengan baik serta melakukan umpan balik terhadap penyampaian hasil diskusi.

Aktivitas merupakan tahapan semua kegiatan siswa dalam pembelajaran. Proses pembelajaran perlu mendorong siswa untuk mengkomunikasikan gagasan hasil kreasi dari temuannya kepada siswa lain, guru, atau pihak-pihak lainnya. Djamarah (2008: 2) mengatakan bahwa "Aktivitas merupakan asas

\section{Jurnal Refleksi Edukatika}

Vol. 6 No. 2 Juni 2016 
terpenting dalam belajar. Belajar adalah aktivitas yang dilakukan oleh individu secara sadar untuk mendapatkan sejumlah kesan dari apa yang telah dipelajari dan sebagai hasil sebagai interaksinya dengan lingkungan sekitar".

Hasil pelaksanaan tindakan dengan menggunakan pendekatan belajar melalui karya poster untuk mengenalkan materi globalisasi mengalami peningkatan dari siklus I hingga siklus II. Aktivitas belajar siswa merupakan hal yang penting dalam pembelajaran. pembelajaran dianggap bermakna jika dalam proses pembelajaran tersebut siswa aktif untuk mencari dan menemukan sendiri pemecahan masalah serta menemukan sendiri pengetahuan melalui pengalaman langsung.

Berdasarkan hasil pengamatan aktivitas belajar siswa secara klasikal pada siklus I pertemuan 1 menunjukkan bahwa aktivitas siswa memperoleh persentase skor $73,63 \%$ dengan kriteria baik dan setelah diadakan tindakan pada pertemuan 2 diperoleh hasil persentase skor $76,93 \%$ dengan kriteria baik. Sehingga aktivitas belajar siswa pada siklus I diperoleh rata-rata persentase mencapai $75,28 \%$ dengan kriteria baik. Berdasarkan hasil pengamatan tersebut peneliti dapat menyimpulkan bahwa dalam pembelajaran masih banyak siswa yang belum dapat mengikuti pembelajaran dengan baik. Masih ada beberapa siswa yang bersifat individualis, siswa belum mampu bekerja sama dengan baik bersama kelompok pasangan, selain itu siswa masih bersikap malu-malu dan ragu untuk mengemukakan pendapat dan mempresentasikan hasil diskusi didepan kelas bersama kelompoknya. Karena perolehan rata-rata persentase klasikal pada siklus I belum mencapai target, maka peneliti melakukan tindakan pada siklus II.

Hasil pengamatan aktivitas belajar siswa pada siklus II pertemuan 1 dalam pembelajaran PKn dengan menggunakan pendekatan belajar melalui karya poster untuk mengenalkan materi globalisasi diperoleh persentase klasikal $80,23 \%$, pada pertemuan 2 diperoleh persentase klasikal 88,98\% sehingga diperoleh rata-rata persentase siklus II mencapai $84,66 \%$ dengan kriteria baik. Berdasarkan hasil pengamatan diketahui bahwa dalam pelaksanaan tindakan siklus II siswa sudah mampu melakukan diskusi dan bekerja sama.

Berdasarkan hasil observasi yang diperoleh pada siklus I dan siklus II dapat diungkapkan bahwa terjadi peningkatan persentase rata-rata aktivitas belajar siswa dari $75,28 \%$ pada siklus I dengan kriteria baik, meningkat menjadi $84,66 \%$ dengan kriteria baik. Peneliti menarik sebuah kesimpulan bahwa terjadi peningkatan terhadap aktivitas siswa menggunakan pendekatan belajar melalui karya poster untuk mengenalkan materi globalisasi kelas IV SDN 1 Ngembalrejo Kudus. Peningkatan aktivitas belajar siswa dalam pembelajaran menggunakan pendekatan belajar melalui karya poster untuk mengenalkan materi globalisasi sejalan dengan penelitian yang dilakukan oleh Ni L. G. Mega Puspita Dewi (2014) Model Pembelajaran Take and Give Berbantuan Media Grafis Terhadap Hasil Belajar PKn SD menunjukkan bahwa model pembelajaran tersebut dapat meningkatkan aktivitas belajar siswa pada siklus I rata-rata mencapai 75,29\% dengan kualifikasi cukup (C), pada siklus II rata-rata mencapai 79,29\% dengan kualifikasi baik (B), dan pada siklus III rata-rata mencapai $83,56 \%$ dengan kualifikasi sangat baik (SB).

Pembelajaran pada hasil belajar siswa ini merupakan hasil observasi dari penelitian yang telah dilakukan oleh peneliti. Penelitian ini dilaksanakan dalam dua siklus dan dilakukan refleksi secara keseluruhan pada tiap siklusnya. Menurut Bloom (dalam Suprijono, 2012: 6) mengatakan hasil belajar siswa meliputi tiga ranah yaitu ranah kognitif, ranah afektif dan ranah psikomotorik. Hasil belajar bukan hanya dilihat dari faktor 
pengetahuan atau pemahaman saja, namun dari segi sikap (afektif) dan psikomotorik siswa juga. Pada dasarnya hakikat belajar adalah perubahan tingkah laku. Menurut Suprijono (2012: 5) mengatakan bahwa hasil belajar adalah pola-pola perbuatan, nilai-nilai, pengertian-pengertian, sikap-sikap, apresiasi dan keterampilan. Pada saat pembelajaran semua aspek yang ada di dalam diri siswa harus terlihat, misalnya dari emosional, mental, fisik, dan sebagainya. Setelah melakukan penelitian selama dua siklus menggunakan pendekatan belajar melalui karya poster untuk mengenalkan materi globalisasi pada pembelajaran PKn kelas IV SDN 1 Ngembalrejo Kudus pada ranah kognitif, afektif dan psikomotorik hasilnya maksimal.

Hasil penelitian tindakan kelas menunjukkan adanya peningkatan hasil belajar PKn menggunakan pendekatan belajar melalui karya poster untuk mengenalkan materi globalisasi. Peningkatan hasil belajar tersebut terbukti dengan data hasil penelitian siklus I dan siklus II. Hal ini dibuktikan dengan adanya peningkatan nilai rata-rata kelas dari prasiklus hingga siklus II. Nilai pada hasil evaluasi pra siklus menggunakan data dari nilai ulangan murni. Berdasarkan data tersebut, diketahui nilai rata-rata siswa 60,45 dengan ketuntasan klasikal 40,91\% terdapat 13 siswa yang belum tuntas dan 9 siswa yang tuntas. Hal ini menunjukkan adanya faktorfaktor yang mempengaruhi hasil belajar siswa.

Menurut Sudjana (2011: 39-40) hasil belajar yang dicapai siswa dipengaruhi oleh dua faktor utama yakni faktor dari dalam diri siswa dan faktor yang datang dari luar diri siswa atau faktor lingkungan. Faktor kemampuan siswa besar sekali pengaruhnya terhadap hasil belajar yang dicapai. Selain faktor kemampuan yang dimiliki siswa, juga ada faktor lain seperti motivasi, minat dan perhatian, sikap dan kebiasaan belajar, ketekunan, sosial ekonomi, faktor fisik dan.
Faktor-faktor tersebut sangat mempengaruhi dalam belajar siswa yang mengakibatkan siswa-siswa tersebut belum tuntas. Faktor lainnya yaitu metode mengajar yang dilakukan oleh guru yang masih menggunakan pembelajaran konvensional. Sehingga mengakibatkan siswa belum tuntas dalam pembelajaran. Hal ini masih jauh dari yang diharapkan, oleh karena itu perlu diadakan penelitian tindakan kelas guna memperbaiki proses pembelajaran agar hasil belajar siswa meningkat.

Hasil belajar evaluasi siklus I menunjukkan rata-rata hasil belajar mendapatkan 69,55 dengan nilai tertinggi 95 dan nilai terendah 50 (selengkapnya pada lampiran 44). Dari 22 siswa yang mengikuti tes akhir siklus I, terdapat 15 siswa yang tuntas $(\mathrm{KKM} \geq 65)$ dan 7 siswa yang tidak tuntas $(\mathrm{KKM}<65)$. Persentase ketuntasan hasil belajar klasikal siswa pada siklus I sebesar $68,18 \%$. Sehingga, dapat disimpulkan bahwa ketuntasan hasil belajar pada siklus I masih belum sesuai dengan yang diharapkan oleh peneliti yaitu mencapai ketuntasan klasikal minimal 75\%. Hal tersebut dikarenakan siswa kurang paham dengan materi yang disampaikan oleh guru dan kemampuan berpikir siswa lebih rendah dari siswa yang lain dilihat dari proses pembelajaran yang berlangsung dan kemampuan siswa dalam menerima materi kurang tanggap dan harus diulang. Untuk mengatasi hal tersebut guru menjelaskan kembali materi yang kurang dipahami siswa dan melakukan perbaikan pada siklus selanjutnya.

Guru melakukan perbaikan dan menyampaikan materi dengan memberikan apersepsi awal atau pemberian materi secara berulang-ulang dalam pembelajaran. Kondisi yang terjadi setelah dilkukan perbaikan yaitu siswa menjadi lebih tanggap dan terjadi peningkatan hasil belajar yang diperolehnya. Siswa juga lebih memahami materi dalam 
pembelajaran yang telah dilakukan. Pelaksanaan tindakan pada siklus II hasil belajar siswa menunjukkan peningkatan yaitu nilai rata-rata hasil belajar siswa pada ranah kognitif mendapatkan rata-rata nilai klasikal 77,05, nilai terendah 60 dan nilai tertinggi 95 (selengkapnya pada lampiran 53). Dari 22 siswa terdapat 19 siswa yang tuntas (dengan $\mathrm{KKM} \geq 65$ ), selain itu 3 siswa belum tuntas. Persentase ketuntasan hasil belajar klasikal siswa pada siklus II sebesar $86,36 \%$.

Pada penelitian ini terdapat siswa yang mengalami gejala naik-turun dari siklus I ke siklus II, siswa tersebut adalah LH, dan LM, dua siswa tersebut termasuk siswa yang aktif, sering mendapat nilai yang baik, dan mendapatkan peringkat I di kelas, siswa ini mengalami gejala penilaian naik-turun karena pengaruh eksternal dari temannya, pada saat dia mengerjakan sering diganggu temannya, dia juga kurang percaya diri dengan jawabannya, meskipun nilainya turun pada siklus ke II, tetapi nilainya masuk dalam kategori tuntas. Sedangkan YM dan SA memiliki sikap yang sama, yaitu suka mengganggu temannya, banyak berbicara dan suka bermain sendiri jika diterangkan oleh guru. Siswa yang bernama NS dan TBS berasal dari keluarga yang cukup, sesuai hasil wawancara dengan guru kelas, siwa ini kurang mendapatkan perhatian dari orang tua, karena orang tuanya terlalu sibuk dengan pekerjaannya yaitu sebagai penjual makanan dan pedagang di pasar. Dia juga tidak mengikuti bimbingan belajar di luar seperti teman-temannya. Jika di kelas dia termasuk siswa yang malas menulis. Sedangkan NR dan ZI termasuk siswa yang aktif dalam pembelajaran, tetapi karena terlalu sering berbicara sendiri saat diterangkan guru, dalam pengerjaan soal siswa ini sering tergesa-gesa, karena ingin cepat selesai dan bermain.

terdapat $\begin{gathered}\text { Gejala naik-turunnya hasil belajar } \\ \text { berbagai faktor yang }\end{gathered}$ mempengaruhinya. Menurut Dimiyati dan
Mudjiono (2009: 239) menyatakan bahwa faktor-faktor yang mempengaruhi proses dan hasil belajar di golongkan menjadi dua, yaitu faktor internal dan faktor eksternal. Faktor internal adalah faktor-faktor yang ada di dalam diri siswa, meliputi kecerdasan, minat dan perhatian, motivasi belajar, ketekunan, sikap, kebiasaan belajar serta kondisi fisik dan kesehatan, sedangkan faktor eksternal faktorfaktor yang berada di luar diri siswa yakni keluarga, sekolah, masyarakat.

Secara keseluruhan terjadi peningkatan hasil belajar dari prasiklus, siklus I dan siklus II. Pada prasiklus rata-rata hasil belajar 60,45 dan mengalami peningkatan pada siklus 1 menjadi 69,55. Peningkatan hasil belajar dari siklus I ke siklus II ditunjukkan dari nilai rata-rata hasil tes yang mengalami peningkatan dari 69,55 pada saat siklus I menjadi 77,05 di siklus II. Ketuntasan belajar siswa dari prasiklus, siklus I sampai siklus II juga mengalami peningkatan. Pada prasiklus siswa yang tuntas hanya $40,91 \%$, sedangkan pada siklus I siswa yang tuntas $68,18 \%$, dan pada siklus II siswa yang tuntas $86,36 \%$. Dari analisis tersebut dapat disimpulkan bahwa rata-rata hasil belajar siswa dan ketuntasan belajar siswa mengalami peningkatan disetiap siklusnya.

Hasil penelitian ini juga diperkuat dengan penelitian yang dilakukan oleh Mulyarsih (2010) yang berjudul "Peningkatan Prestasi Belajar IPS Melalui Media Poster Pada Siswa Kelas IV SDN Harjowinangun 01, Tersono Batang". Dari hasil penelitiannya, diketahui bahwa hasil belajar siswa meningkat. Pada tes awal rata-rata hasil belajar siswa mencapai 66,06 , Siklus I ratarata 67,73 , Siklus II rata-rata 73,2 dan Siklus III rata-rata 82,06.

Hasil belajar afektif siswa di siklus I dan II menggunakan pendekatan belajar melalui karya poster untuk mengenalkan materi globalisasi menunjukkan peningkatan 
tiap siklusnya. Ada 5 indikator yang digunakan peneliti dalam menilai hasil belajar afektif siswa, diantaranya:

(1) Kesiapan untuk menerima pelajaran

(2) menjawab pertanyaan dari guru/teman

(3) memperhatikan penjelasan guru/teman (4) menanggapi masalah yang diajukan guru, (5) menanggapi hasil diskusi.

Pada lima indikator yang dikembangkan sendiri oleh peneliti, hasil belajar afektif tersebut mengandung nilai dan sikap yang terlihat pada proses pembelajaran PKn, senada dengan itu, Sudjana (2013:30) mengatakan bahwa "tipe hasil belajar afektif tampak pada siswa dalam berbagai tingkah laku seperti perhatiannya terhadap pelajaran, displin, motivasi belajar, menghargai guru dan teman sekelas". Pelaksanaan tindakan kelas pada proses pembelajaran $\mathrm{PKn}$ menggunakan pendekatan belajar melalui karya poster untuk mengenalkan materi globalisasi menunjukkan hasil belajar ranah afektif siswa dari siklus I ke siklus II mengalami peningkatan ditinjau dari persentase yang diperoleh siswa. Siklus I menunjukkan hasil belajar ranah afektif siswa memperoleh rata-rata $62,5 \%$ sedangkan pada siklus II memperoleh skor rata-rata $84,43 \%$. Hal tersebut menunjukkan peningkatan sebesar $21,93 \%$.

Berdasarkan pada pembahasan diatas dapat disimpulkan bahwa pada siklus II hasil belajar siswa mengalami peningkatan dibanding siklus I maupun pra siklus. Hal tersebut menunjukkan bahwa menggunakan pendekatan belajar melalui karya poster untuk mengenalkan materi globalisasi dalam pembelajaran PKn kelas IV SDN 1 Ngembalrejo Kudus mampu meningkatkan hasil belajar siswa.

Pada hasil belajar psikomotorik siswa di siklus I dan II menggunakan pendekatan belajar melalui karya poster untuk mengenalkan materi globalisasi menunjukkan peningkatan tiap siklusnya. Ada 5 indikator yang digunakan peneliti dalam menilai hasil belajar afektif siswa, diantaranya (1) Terampil dalam melakukan kegiatan menyelesaikan permasalahan yang diberikan guru, (2) Bekerja sama/ berdiskusi untuk menyelesaikan masalah, (3) Mengajukan pertanyaan, (4) Mengemukakan pendapat, (5) Membuat kesimpulan.

Dari beberapa indikator di atas merupakan hasil dari pengembangan tingkatan keterampilan motorik dalam pembelajaran. Menurut Sudjana (2013:23) menyebutkan bahwa ranah psikomotoris berkenaan dengan hasil belajar keterampilan dan kemampuan bertindak. Pelaksanaan tindakan kelas pada proses pembelajaran PKn menggunakan pendekatan belajar melalui karya poster untuk mengenalkan materi globalisasi menunjukkan hasil belajar ranah psikomotorik dari siklus I ke Siklus II mengalami peningkatan.

Siklus I menunjukkan hasil belajar psikomotorik siswa memperoleh nilai klasikal 56,02\% Dengan kualifikasi cukup. Pada siklus I, menunjukkan sikap siap dalam mengikuti pembelajaran serta kepatuhan siswa dalam mengikuti arahan guru, namun masih ada kekurangan pada saat siswa mempersiapkan diri mengikuti pembelajaran. Masih banyak siswa yang ramai pada saat pelajaran akan dimulai, bahkan juga ada pada saat pembelajaran berlangsung. Terlihat juga peningkatan pada siklus II memperoleh nilai klasikal 84,21\% dengan criteria baik. Hal tersebut menunjukkan menggunakan pendekatan belajar melalui karya poster untuk mengenalkan materi globalisasi dapat meningkatkan hasil belajar psikomotorik siswa.

Media poster merupakan suatu gambar yang mengkombinasi unsur-unsur visual seperti garis, gambar dan kata-kata yang bermaksud menarik perhatian serta mengkombinasi pesan secara singkat (Sudjana dan Rivai, 2001: 12).

\section{Jurnal Refleksi Edukatika}

Vol. 6 No. 2 Juni 2016 
Dengan memberikan media berupa karya poster pada materi globalisasi diharapkan siswa kelas IV SDN 1 Ngembalrejo Kudus dapat memahami materi pengaruh dan akibat yang terjadi pada globalisasi sebab media poster memiliki kelebihan sebagai pesan (dan informasi dengan bentuk dua dimensi dari suatu sumber (Resource) kepada penerimanya (Receiver). Satu hal yang paling penting, media poster yang diterapkan dengan ukuran tepat memungkinkan setiap siswa untuk belajar materi globalisasi dengan mengaktifkan otak bawah sadar mereka. Atas dasar hasil tersebut dapat disimpulkan menggunakan media karya poster sebagai salah satu media alternatif dalam pembelajaran PKn untuk memahami materi globalisasi.

Hasil penelitian menunjukkan bahwa penggunaan media karya poster sebagai media pembelajaran PKn dapat meningkatkan hasil belajar siswa kelas IV SDN 1 Ngembalrejo Kudus dengan nilai rata-rata pada siklus I sampai siklus II menjadi lebih efektif dengan hasil $73,08 \%$ dan $92,30 \%$.

\section{KESIMPULAN DAN SARAN}

Berdasarkan hasil penelitian tindakan kelas yang dilakukan pada siswa kelas IV SDN 1 Ngembalrejo Kudus dapat disimpulkan bahwa ada peningkatan hasil belajar siswa menggunakan pendekatan belajar melalui karya poster untuk mengenalkan materi globalisasi dapat dilihat.

a) Keterampilan mengajar guru dalam mengelola kelas pada pembelajaran PKn menggunakan pendekatan belajar melalui karya poster untuk mengenalkan materi globalisasi pada siklus I memperoleh persentase $80,17 \%$ berada pada kriteria baik, pada siklus II meningkat menjadi $84,91 \%$ dengan kriteria baik.

b) Aktivitas siswa dalam mengikuti Pembelajaran PKn materi globalisasi menggunakan pendekatan belajar melalui karya poster untuk mengenalkan materi globalisasi pada siklus I memperoleh $75,28 \%$ berada pada kriteria baik,meningkat pada sikus II menjadi $84,66 \%$ berada pada kriteria sangat baik.

c) Pembelajaran PKn menggunakan pendekatan belajar melalui karya poster untuk mengenalkan materi globalisasi dapat meningkatkan hasil belajar pada aspek kognitif, afektif dan psikomotorik. Peningkatan pada aspek kognitif dilihat pada siklus I ke siklus II yaitu nilai rata-rata 69,55 naik menjadi 77,05, Pada aspek afektif dilihat dari siklus I ke siklus II yaitu dari $62,5 \%$ kriteria cukup naik menjadi $84,43 \%$, dengan kriteria baik, Sedangkan Pada aspek psikomotorik dilihat siklus I ke siklus II yaitu dari $56,02 \%$ kriteria cukup naik menjadi $84,21 \%$ berada pada kriteria baik.

2. Saran

a) Bagi Siswa

1). Seorang siswa hendaknya mendengarkan dengan sungguhsungguh ketika guru menjelaskan materi globalisasi.

2). Sebaiknya siswa tidak mudah bosan dalam mengikuti pembelajaran yang diajarkan oleh seorang guru. Siswa harus bisa menanamkan rasa senang dalam pembelajaran agar bisa semangat dalam mengikuti pembelajarannya.

3). Sebaiknya siswa tidak perlu malu bertanya pada guru apabila ada sesuatu yang menurutnya masih kurang jelas.

4). Sebaiknya siswa terbiasa untuk mengadakan belajar kelompok, agar lebih mudah memecahkan suatu permasalahan.

5). Sebaiknya kelompok yang sudah selesai dalam mengerjakan tidak gaduh atau mengganggu temannya, seharusnya mereka mengoreksi kembali pekerjaannya sehingga tidak 
mengganggu kelompok lain yang belum selesai mengerjakan.

6) Siswa hendaknya berlatih untuk meningkatkan keberanian maju di depan kelas ketika diminta guru mempresentasikan hasil diskusi kelompoknya.

b).Bagi Guru

1). Sebaiknya dalam melaksanakan kegiatan pembelajaran guru hendaknya jangan terpaku dengan pembelajaran yang sifatnya konvensional yang lebih mudah digunakan, melainkan guru hendaknya harus menggunakan model pembelajaran inovatif yang sesuai dengan karakteristik siswa dan dapat merangsang siswa agar mau belajar.

2). Pendekatan belajar melalui karya poster untuk mengenalkan materi globalisasi dapat digunakan guru sebagai model pembelajaran dalam pelaksanaan proses pembelajaran, karena model tersebut dapat melatih siswa berani mengemukakan pendapat dan berpikir kritis

3). Guru sebaiknya lebih mengoptimalkan perannya sebagai motivator dan fasilitator dengan memberikan motivasi belajar, pengelolaan kelas yang baik, dan memberikan kesempatan siswa untuk mengembangkan cara berpikir dan kreativitas dalam memecahkan suatu permasalahan.

\section{DAFTAR PUSTAKA}

Arikunto, Suharsimi. 2010. Prosedur Penelitian: Suatu Pendekatan Praktik Jakarta: RinekaCipta.
Dimyati dan Mudjiono. 2009. Belajar dan Pembelajaran. Jakarta: RinekaCipta

Djamarah, Syaiful Bahri. 2008. Psikologi Belajar. Jakarta: Rineka Cipta.

Belajar. Jakarta: Rineka Cipta.

Belajar. Jakarta: Rineka Cipta.

Mastur, Wiyono, W. 2007. Buku Pendidikan Kewarganegaraan. Semarang : Aneka Ilmu.Ni L. G. Mega Puspita Dewi. 2014. Model Pembelajaran Take And Give Berbantuan Media Grafis Terhadap Hasil Belajar PKn SD. Jurnal Mimbar Volume. 2 No:1. PGSD Universitas Pendidikan Ganesha.

Sanaky, Hajar AH. 2009. Media Pembelajaran. Yogyakarta: Safiria Insania Press.

Sudjana, Nana. 2012. Penilaian Hasil Proses Belajar Mengajar. Bandung: PT RemajaRosdakarya.

Suprijono, Agus. 2012. Cooperative Learning Teori\&Aplikasi PAIKEM. Yogyakarta: PustakaBelajar.

Suwandi. 2011. Penelitian Tindakan Kelas (PTK) dan Penulisan Karya Ilmiah. Surakarta: Yuma Pustaka.

Mudjiono. 2009. Belajar dan Pembelajaran. Jakarta: RinekaCipta 